Perspectivas - Portuguese Journal of Political Science and International Relations, N. ${ }^{\circ}$ 8, October 2012, 101-123 (c) NICPRI 2012

\title{
Violência Política: Do Estado à Subversão do Estado - Análise sobre um Modelo Conceptual
}

Felipe Pathé Duarte

Felipe Pathé Duarte

Associate Professor at the Institute for Business

Communication, Lisbon

Invited Professor at the Higher Institute of Police Sciences and

Internal Security, Lisbon

Researcher at Portuguese Catholique University - Institute

for Political Studies, Lisbon

Executive Member of the Portuguese Observatory for

Security, Organized Crime and Terrorism

felipepatheduarte@gmail.com 
RESUMO:

Este é um artigo conceptual, antológico e descritivo. Referir-nosemos aos problemas do foro teórico relacionados com a definição de violência e associamo-la não só ao exercício do poder como à sua derrocada. Expomo-la aqui de uma perspectiva dialéctica. Em primeiro é analisada a violência como forma de constituição de Estado; em segundo como forma de manutenção de Estado; e, por último, como forma de destruição de Estado. Ou seja, nas duas primeiras perspectivas a violência é vista como elemento institucional, para na última ser analisada como forma de por em causa essa mesma dimensão institucional. Entramos assim no campo da subversão. $\mathrm{O}$ artigo refere-se então a representações conceptuais que vêem na violência uma dimensão instrumental, estruturada ou nãoestruturada, garante de possível transformação ou subsistência política, quer ao nível institucional ou nãoinstitucional. Falamos assim da violência como continuação da política, mas por outros meios.

PALAVRAS-CHAVE: Estado, Violência Política, Subversão e Subversão Armada.
A violência é a parteira de toda a sociedade velha grávida de uma nova.

Karl Marx, Capital, Vol. 1, Part VIII, Cap. XXXI (1867)

$A$ arma de um combatente é a sua humanidade. Num primeiro tempo da revolta, é preciso usar a violência: abater um europeu é matar dois coelhos de uma cajadada, suprimir ao mesmo tempo um opressor e um oprimido, sobrando daí um homem morto e um homem livre.

Jean-Paul Sarte, prefácio de Les Damnés de la Terre (Frantz Fanon, 1961)

\section{a) Sobre a violência}

A violência é caracterizada pela sua ubiquidade. É uma característica indelével do Homem que pode assumir diversas formas. Definir, limitar e balizar este fenómeno revela-se uma tarefa na prática impossível - e, em todo o caso, de pouca utilidade analítica. Porém, fechando o nosso campo de abordagem, é importante referir que atentaremos apenas à violência que tem como força motriz uma dimensão política. Porquanto, neste ensaio, quando falamos de violência, referimo-nos sempre à violência política. No entanto, para iniciar o caminho conceptual, partiremos de uma definição mais generalista que se refere a todo o tipo de violência, definindo-a como intervenção de uma vontade humana que "procura sobrepor-se a uma ordem de existência, de forma a alterar uma situação, modificar comportamento de uma pessoa ou conjunto de pessoas, ou, pura e simplesmente, para as coagir ou suprimir». ${ }^{1}$ Mas, não nos cabe aqui fazer uma análise deste processo, que é usado por uns sobre outros para impor o(s) seu(s) objectivo(s), e que é tão antigo como a existência do Homem.

Se atentarmos à bibliografia no âmbito das Relações Internacionais ou Teoria Política, podemos encontrar variadíssimas formas de conceptualizar e definir a violência. Embora haja algumas diferenças, em quase todas elas a violência está associada à força como forma de levar outrem a se submeter a uma vontade. Como instrumento delimitador estas conceptualizações de pouco nos servem. Para além de estarem associadas com frequência a outros conceitos inter-relacionados (como agressividade, uso da força, guerra...), das duas uma: ou são demasiado redutoras, afundando-se na proximidade à questão dos danos físicos, ou se perdem na generalização, como sendo a violação de qualquer vontade ou direito. Por outro lado, também não se verifica a enfatização da diferença entre a violência e conceitos que lhe são familiares (como poder, autoridade, força, guerra...).

Podemos então dizer que há duas formas de conceptualizar a violência: uma que parte da violência como força, e outra que a procura entender como violação. ${ }^{2} \mathrm{Com}$ 
efeito, é bastante comum entender a violência como a expressão de força contra um ou mais indivíduos, pondo em causa a sua integridade física e psicológica.

Na ideia de violência está sempre latente o uso da força. ${ }^{3}$ Porém, a força é um conceito disposicional e refere-se a qualquer coisa em potência. A violência refere-se à acção em si, tendo por isso um carácter qualificativo e, por vezes, até normativo ${ }^{4}$ - atributos que vamos encontrar no conceito de força. Hannah Arendt, a quem regressaremos posteriormente com mais precisão, põe de parte a conceptualização de violência como sinónimo de força. ${ }^{5}$ Aliás, Arendt empreende a tarefa de as definir muito bem: força como sendo libertação de energia (força das circunstâncias e da natureza), que não é o mesmo que violência. ${ }^{6}$ Verificamos então que, contrariamente ao conceito de violência, há uma certa neutralidade moral no conceito de força Violência, por isso, não pode ser definida como uso da força física.

A violência como violação é encarada sobretudo como transgressão de limites e/ou normas. Aqui, para além de se ter em conta componente física do humano, conta-se também com a sua dignidade. Temos então a violência na sua forma física e na sua forma psicológica.

Entrando um pouco mais no campo da Sociologia, podemos ainda definir a violência em oposição ao conflito. Por dimensão conflitual entendemos, em sentido restrito, uma relação desigual entre dois (ou mais) indivíduos, grupos ou conjuntos grupais, que competem, dentro do mesmo espaço, procurando a não anulação do adversário ou da relação, mas a modificação dessa mesma relação e/ou a optimização das posições em divergência. Neste sentido, o conflito é oposto à ruptura, que procura a anulação do adversário e não significa necessariamente guerra (no sentido polemológico do termo). Em suma, conflito, nesta análise, ainda não é ruptura nem implica necessariamente o uso da violência. ${ }^{7}$ No campo desta noção de conflito não há inimigos no sentido schimittiano ${ }^{8}$, mas adversários cuja situação conflitual poderá ser institucionalizada (através de formas negociais, por ex. ${ }^{9}$ ). Seguindo a linha sociológica de Georg Simmel, sendo a sociedade um processo de interacção de indivíduos, o conflito é sempre positivo. A sua antinomia, pela indiferença e neutralidade, é por isso o fim de toda a interacção. ${ }^{10}$

Porém, é no limite desta noção de conflito que entra a violência, que vai, senão inviabilizar, pelo menos dificultar toda e qualquer solução lograda por via de um percurso. Portanto, o que os distingue é a já referida interacção, presente no conflito e ausente na violência que a aniquila - pois há uma objectivação do adversário e a subsequente anulação da alteridade. Violência é, por isso, a ruptura e anulação 
de outra vontade. Contudo, há que ter em conta que esta separação paradoxal entre conflito e violência não pode ser encarada como uma regra absoluta. Há casos em que o conflito, radical, prevê o uso de uma violência instrumental, e não essencial, como fruto de uma expressão calculada e controlada pelos actores do conflito. É caso disso a violência de carácter político.

Chegados a este ponto, podemos então afirmar que há violência quando, numa situação de interacção, um ou mais actores agem de forma directa ou indirecta, aglomerada ou dispersa, infligindo danos a um ou vários indivíduos, e em graus variáveis - integridade física e/ou moral, bens materiais, ou dimensão simbólica e/ou cultural -, visando a possível anulação da sua vontade.

\section{b) A violência como fundadora de Estado: de Thomas Hobbes a Max Weber}

Comecemos pois por dizer que, associado à criação de um Estado, e ao seu exercício de poder, está latente o uso da violência. Entramos assim numa ambivalência. Por um lado, como referiremos adiante, temos a violência como destruidora e motor de corrosão de um poder legítimo; e por outro, está a violência como fundadora de Estado, ou, se quisermos, de um poder legítimo. Será por aí que agora vamos entrar, tentando analisar - balizando epistemologicamente no seio da Filosofia Política - a violência como fundadora do Estado, e este como legítimo perpetrador de violência (violência estrutural), para no fim chegarmos à subversão como violência não legitimada e corrosiva de Estado. Note-se que nos três casos a violência é sempre instrumental.

É importante também referir que tivemos em consideração a profusão de autores e correntes que analisam e conceptualizam esta temática. Porém, para evitar a dispersão no que diz respeito à associação da violência ao Estado, cingir-nos-emos apenas, ainda que de uma forma superficial, aos teóricos clássicos, não marxistas, para interpretar a violência como instrumento do Estado. Equacionada esta relação, teremos também em conta uma perspectiva crítica que fará apologia a uma violência pura e não mediadora - fundamental para intelectualizar algumas formas de acção subversivas. Contudo, será um erro se se der a entender que a teoria do Estado e do poder se circunscreve somente aos autores que abordaremos. Numa terceira fase, sobre a violência como instrumento de subversão do Estado, referir-nos-emos então a autores que, de uma forma directa ou indirecta, beberam de Karl Marx e G. W. Friedrich Hegel. 
Deste modo, pretendemos delinear um enquadramento que nos permita caracterizar o Estado (seja qual forma for) como legítimo monopolizador da violência, para posteriormente podermos entender a subversão como a quebra dessa monopolização, e que, pela acção violenta, procura a possível legitimidade. A nossa estratégia final passa assim por compreender a subversão como um exercício ilegítimo de poder anti/para-Estatal.

Parece-nos agora pertinente começar com o anarco-sindicalista francês George Sorel, quando nos diz que os problemas da violência permanecem ainda muitos obscuros. ${ }^{11}$ À parte esta heterodoxia inicial, que nos ajuda a ilustrar a dificuldade conceptual da análise que nos propomos fazer, podemos então dizer que a violência está associada ao poder. Pois a violência não deixa de ser uma forma de manifestação de poder. Mas o que é o poder? O poder é aqui encarado como sendo um instrumento de dominação. Neste registo, parafraseando Hannah Arendt, não há nenhum poder maior do que aquele que provém do cano de uma arma. ${ }^{12}$

Mas, para dissecar os conceitos de poder, violência e Estado, é-nos inevitável não recorrer a Thomas Hobbes, um dos primeiros pensadores do Estado moderno. ${ }^{13}$ Em todo o seu pensamento está latente que, sem um poder forte, a humanidade autodestrói-se. Hobbes justifica a origem da violência no facto de todos os homens serem iguais. Nesta condição todos sentem o mesmo direito sobre todas as coisas, dispondo também dos mesmos meios para as obter. Assim se deduz que a igualdade natural entre os homens é razão da sua rivalidade e da sua violência - «e, portanto, se os dois homens desejam a mesma coisa, que, no entanto, eles não podem desfrutar, tornam-se inimigos». ${ }^{14}$

É com este panorama que o filósofo postula o Estado de Natureza - uma ficção teórica e retórica para demonstrar o estado em que se encontram os homens sem lei e sem poder, dominados apenas pelo instinto de conservação. É o estado da guerra de todos contra todos (bellum omnium contra omnes).$^{15} \mathrm{E}$ é quando o homem se transforma em lobo do próprio homem (homo homini lupus), dirá Hobbes. ${ }^{16}$ Será a mesma racionalidade e angústia de finitude que o levam ao estado de guerra. Elevam-no à sua fuga, isto é, ao abandono do Estado de Natureza e da atomização social.

Sair deste estado implica aos homens abdicação do seu direito natural, pois transfere-se esse direito para uma soberania comum, em prol da ordem e da segurança, que exercerá o poder. Ou seja, há uma renúncia de um direito inalienável que é confiada a um terceiro, um soberano que monopolizará a violência que 
cada um empregaria na defesa de si próprio. De acordo com Hobbes, é desse contrato e do controlo sobre a violência que nasce um Estado legitimado. A violência está portanto na base da fundação de um Estado. ${ }^{17}$

Na senda de Hobbes, para além da fundação e preservação do Estado pela violência, há que ter em conta dois pontos importantes para compreender a dinâmica Estado versus subversão. Sem entrar muito no foro da Filosofia Política, podemos dar relevo ao paradigma que equaciona liberdade e soberania - e daqui surge a questão sobre que grau de obediência pode um poder legítimo exigir sem ultrapassar o seu direito. Num outro nível destacamos o facto de que, perante a igualdade que nos marca, não há diferença para justificar a vantagem de quem exerce a soberania ${ }^{18}$ - daqui faz sentido indagar acerca do grau de liberdade que os homens que vivem em comunidade podem legitimamente reclamar sem, contudo, ameaçar a paz civil.

Já nos apercebemos então que a relação do Estado com a violência pode ser conceptualmente ubíqua. Mas será com Max Weber, no ensaio Politik als Beruf, que o jargão do Estado como legítimo monopolizador da violência ganha uma dimensão paradigmática. ${ }^{19}$ Esta perspectiva de Weber não deixa de ser uma reminiscência do pensamento de Thomas Hobbes, na qual o Homem, por medo da violência e consequente aniquilação, ergue um Estado que reivindica o monopólio legítimo da violência como forma de protecção e segurança num determinado território.

Em Weber o Estado consiste numa relação de dominação, do homem pelo homem, com base no uso legítimo da violência. Porém, essa violência não é o único instrumento de domínio do Estado, mas é seu instrumento específico, havendo, por isso, uma relação íntima do Estado com a violência.

Sem mergulhar muito no pensamento de Weber sobre o Estado, porque não é este o propósito do ensaio, podemos dizer que à componente violenta do Estado se juntam outros traços: a racionalização do Direito com as consequências e a especialização dos poderes legislativo e judiciário; a instituição de uma polícia encarregada de proteger a segurança dos indivíduos e de assegurar a ordem pública; forças armadas permanentes; uma administração racional baseada em regulamentos explícitos que lhe permitem intervir nos domínios mais diversos, desde a educação até a saúde, à economia e até mesmo na cultura.

Partindo de Leon Trotsky, quando diz que um Estado é fundado na força, Weber refere que se apenas existissem estruturas sociais e que se a violência não estivesse presente, seria o princípio do Estado que desapareceria, reinando a 
anarquia. Conjugando os conceitos de domínio (aplicação da administração via funcionalismo, militar ou civil) como forma de poder, de uma comunidade humana dentro de limites territoriais e da monopolização legítima da força, este sociólogo alemão concebe o princípio do Estado moderno.

A outra questão tratada por Weber, e não de somenos importância, passa pela legitimidade de poder. Há que ter em conta que o poder, que tem como forma de exercício o domínio, não se mantém só pela aplicação da força. Assim, na obra Wirtschaft und Gesellschaft ("Economia e Sociedade") distingue três tipos ideais de dominação legítima - "tradicional" (patriarcal e hereditária), a "carismática" (dom pessoal - carisma) e a "racional" (burocrática e legal). ${ }^{20}$ No primeiro a autoridade passa por costumes enraizados numa sociedade como o poder patriarcal ou proprietário, ou seja, o teor da ordem e do domínio está fixado na tradição social e cultural. A autoridade é exercida por um privilégio legitimado numa tradição de usos e costumes. Seguidamente temos a legitimidade de poder que assenta no carisma e no valor pessoal. É exemplo deste tipo ideal de dominação o poder exercido por um profeta, por um dirigente eleito, por um demagogo ou por soberano também eleito. E por último, temos a liderança racional que assenta nas leis e no Direito, fundamenta-se na validade de um estatuto legal e numa organização estruturada em regras racionalmente estabelecidas. A mais óbvia forma do domínio racional legal é a burocracia. Esta é legitimidade de poder exercida pelo Estado moderno, território de pragmatismo e eficácia instrumental.

O que importa retirar destes dois autores, Hobbes e Weber, é que, de uma forma teórica e partindo de categorias abstractas, associam o Estado à legitimidade do uso da violência, bem como à sua fundação. Parece também não haver uma distinção entre domínio, que é exercício de poder, violência e autoridade. Embora a categorização de legitimidade do uso da violência pareça reduzida ao anacronismo (ponto que será explorado adiante), o facto é que o Estado permanece como a fórmula política que garante o seu controlo e a sua não disseminação para fora das suas esferas de influência.

A ideia de Estado Natureza ou de anarquia não se revelam aqui como conjunturas epocais, mas como princípios internos ao Estado que se lhe revelam na possibilidade da sua dissolução. A sua dissolução, como poder legítimo, poderá ocorrer não só por situações de desastres naturais, por exemplo, ou pela rebelião incontrolada da massa governada, mas também pela promoção de um "Estado de emergência". Numa tal situação são suspensos os direitos civis, e a violência, que fundou o Estado, institucionaliza-se. 
Ainda assim, e regressando a Hannah Arendt, resta-nos distinguir poder de violência, pois estes dois conceitos não poderão ser encarados como sinónimos. ${ }^{21} \mathrm{O}$ poder pode caracterizar-se como sendo a faculdade de exercer sobre um homem uma tal dominação que dele se conseguirão obter actos ou comportamentos que não seriam espontâneos. A questão passa agora por tentar perceber como é que o poder se exerce e se estabelece, e através de que meio se pode conseguir uma obediência. Para se fazer respeitar e impor, o poder recorre à força e à violência. Daí a simples associação entre os dois conceitos.

Contudo, há que ter em conta que o poder é parte essencial de todo um governo, mas a violência e a força não o são, ou pelo menos não o deveriam ser, segundo Arendt. Desta forma revela-se, uma vez mais, o carácter instrumental da violência, que apenas necessita de orientação e justificação para o seu desencadeamento, pois o poder pode ser conquistado pela força e pela violência, mas nunca conseguirá manter-se através delas. Quando o domínio vem somente pela violência, o poder está então em vias de ser perdido pois está em aberto o caminho para a deslegitimação.

É na vitória da violência sobre o poder que, de acordo com Arendt, passa o terror, ou seja, "é quando a violência, após destruir todo o poder não abdica, mas, ao contrário, permanece mantendo todo o controlo». ${ }^{22}$ Nesta fase, a violência já não é suportada pelo poder, que, embora tenha sido instalado pela acção violenta, surge como restrição a essa forma de acção. Os meios passam agora a determinar os fins - sendo que estes visam a destruição de todo e qualquer poder. ${ }^{23}$ Verifica-se que, para além de dissociados, a violência e o poder são conceitos opostos - quando um domina de forma absoluta o outro está ausente. O primeiro surge quando o segundo se encontra ameaçado - mas se permanece, aniquila-o. A violência pode destruir o poder mas não o gera.

\section{c) A violência como preservação de Estado: perspectiva crítica de Walter Benjamin}

Depois da violência como fundadora de Estado, faz agora sentido falar da violência também como preservadora do Estado. Fá-lo-emos de uma perspectiva crítica $^{24}$, sugerindo a violência do Estado como um factor da sua deslegitimação e a existência de uma outra forma de violência que vai além do funcionalismo dialéctico apontado anteriormente. Daqui serão abertas as portas conceptuais para a subversão do Estado. 
Afastando-nos dos grandes teóricos do Estado, não nos parece totalmente descabido recorrer agora a Walter Benjamin. De que maneira e com que intuito? Na obra de 1921, Zur Kritik der Gewalt ${ }^{25}$ ("Para uma Crítica da Violência") Benjamin faz um jogo semântico com a palavra Gewalt ${ }^{26}$ e aponta a origem do direito/lei (e do poder judiciário) no espírito da violência. Todo o texto oscila entre dois pólos: a violência e o poder. A análise teve a montante a derrota germânica na I Grande Guerra e o posterior caos parlamentar associado à República de Weimar. E é na sombra dos escritos de George Sore ${ }^{27}$ e em diálogo com Carl Schmitt ${ }^{28}$, que este autor, de cariz marxista, redige o ensaio.

Walter Benjamin vem então apontar o dedo à concepção instrumental da violência (verificada, por exemplo, em Thomas Hobbes, Carl von Clausewitz, Max Weber ou Friederich Engels - como verificámos), não a negando, mas, na senda de Sorel, propondo uma violência pura, fora dessa instrumentalidade e que seja um fim em si.

Fazendo uma dicotomia entre fins justos ou injustos, e os meios para os alcançar, Benjamin alude à insuficiência quer do direito natural quer do direito positivo para justiçar a acção violenta. O direito natural tenta, pela justiça dos fins, justificar os meios. O direito positivo tenta garantir a justiça dos fins pela justificação dos meios. Na concepção jusnaturalista a violência é um produto natural, apenas condenável se usada para fins injustos. As concepções apontadas anteriormente (de Hobbes a Weber, e até a da não referida Revolução Francesa) assentam neste princípio jusnaturalista - há um despojamento de toda a autoridade natural do indivíduo para o Estado, que exerce a sua magistratura legitimada também pelo facto de que antes do contrato estabelecido, o indivíduo exerce de jure todo o poder que tem de facto. ${ }^{29}$ A condenação ou legitimidade do uso de violência parte da avaliação dos fins.

Por outro lado, temos o direito positivo que considera o poder no seu contexto e dimensão histórica, e onde o julgamento residirá apenas na crítica dos meios. O jusnaturalismo procura justificar os meios pela justiça dos fins, o juspositivismo tenta garantir a justiça dos fins através da legitimação dos meios. Mas esta dicotomia torna-se insuperável se os fins entrarem em contradição com os meios. A grande questão para este filósofo alemão é a possibilidade de uma análise crítica da violência, e na possibilidade de a pensar, não na justiça dos fins, mas na violência como um puro meio.

Vendo esta insuficiência, Walter Benjamin procura um ponto focal externo à filosofia do juspositivismo e à do jusnaturalismo. Neste ensaio recorda então 
os usos legais da violência, incluindo os momentos em que o Estado renuncia, parcialmente, ao seu monopólio sobre o uso legal da violência. E um dos casos, por exemplo, será o direito à greve. O que conta é, de facto, o critério estabelecido para fins justos e meios legítimos. Benjamin vai acabar por partir dos dois registos, o jusnaturalismo e o juspositivismo, para fundamentar a crítica e depois encontrar uma perspectiva fora deles.

A violência, como meio, ou funda ou conserva a lei. Deixando de ter esse propósito, renuncia por si mesma toda a validade. Todavia, pode haver o caso de um tipo de violência que não se submete à dialéctica de fins e meios. Benjamin, no ensaio, dá três exemplos que excedem essa distinção dialéctica - uma greve geral, um grande delinquente e a pena de morte. Estes exemplos ajudam a perceber que "dentro" da lei está uma violência "fora" da lei, e que esta constitui uma ameaça à legitimidade da primeira.

$\mathrm{O}$ autor alemão considera uma lei como decadente pelo facto de ter de se impor e se reafirmar pela violência. Está pois deslegitimada, sustentando-se apenas pela força, que, de uma certa forma, vem ocupar o vazio deixado pela falta de legitimidade. Tal como frisámos há pouco, para Benjamin, há, portanto, uma violência instauradora/fundadora de lei (rechtsetzend Gewalt) e uma violência que a mantém (rechtserhaltende Gewalt). A primeira estabelece a fronteira entre o que é legal e ilegal. A segunda manterá a fronteira decidida na primeira. Por outro lado, considera ainda a chamada violência revolucionária, fundadora de um outro Direito, por oposição à violência preservadora (de lei/direito) que opera dentro da legalidade existente. Mas há que não confundir a vertente revolucionária com a instauradora/fundadora de lei/direito. Para Benjamin, a rechtsetzend Gewalt nunca é revolucionária.

Neste âmbito, o autor refere-se à violência militar como sendo a compulsão ao uso universal da violência como meio para fins de Estado ${ }^{30}$ - ou seja, construção de novas formas legais. Portanto, a violência militar é uma violência fundadora. De acordo com Walter Benjamin, o poder/violência da polícia (Polizeigewalt) aparece como sendo uma sombra espectral que concilia as duas formas de violência (de fundação e de manutenção). É um registo criado pelo Estado que permite a suspensão da diferença entre as duas violências. A violência fundadora de nova lei/direito tem que se provar vitoriosa. A violência que mantém essa lei/direito está restrita aos fins, mas a violência policial não tem que provar vitória, nem está resignada a operar dentro da legalidade. É o instrumento da lei/direito, mas não se deixa subsumir a ela. 
Benjamin faz ainda uma distinção entre outras formas de violência - a "mítica" e a "divina". Refere que, no que diz respeito à legitimidade dos meios e à justiça dos fins, a razão não decide - no caso da primeira, a "mítica", é a violência, no caso da segunda, a "divina", será Deus. ${ }^{31}$ Os fins justos, passíveis de universalização, surgem de uma violência não mediatizada, uma violência imediata, aniquiladora e pura. Falamos de uma violência ética por excelência, que inaugura uma época e não é mera repetição histórica..$^{32}$ É uma violência que está para além da lei/direito, e que Benjamin denomina de "divina".

A violência "mítica" é a manifestação dos deuses. Partindo da dimensão representacional do mito, alude, portanto, a uma violência arquetípica criadora de Direito, que não surge como um meio para um fim, mas apenas como uma manifestação da vontade. ${ }^{33}$ É uma violência que vem por ordem do destino, mas não é propriamente destruidora. Surge fora da dimensão histórica, mas é garante da sua possibilidade. E como se poderá verificar é próxima à violência instituinte da lei, pois restitui essa violência pura à esfera da lei/direito, convertendo-a numa violência fundadora permanente: é um "Estado de excepção" transformado em regra. É um sacrifício que funda a possibilidade de um pacto social. Esta violência "mítica" funciona como uma espécie de totem ancestral que desperta de modo espectral. Uma tal situação sente-se, sobretudo, em regimes totalitários. Desta forma, a função do poder/violência na institucionalização da lei é dupla - procura aquilo que é instituído como Direito (fim) através da violência (meio); depois da institucionalização do fim, não dispensa a violência. A violência "mítica" parece obedecer à estrutura dialéctica da violência fundacional e conservadora. Mas Benjamin vai além desta dicotomia, mostra que ambas as violências (fundadoras e conservadoras) são dois momentos da mesma violência, a "mítica", que se opõe à "divina". Se a primeira é criadora de direito, a segunda destrói-o. Se uma culpa a outra desculpa. ${ }^{34}$

Em suma, o autor apela à destruição da violência "mítica" pela violência "divina". Há uma proposta de política de mediação pura. ${ }^{35}$ É igualmente interessante verificar que Benjamim destaca a diferença entre a violência de um movimento revolucionário que tenta tomar o poder Estatal e a violência de um movimento que, ao contrário, tenta destruir o poder do Estado rejeitando qualquer relação com a lei. Essa segunda forma de violência é pura ou imediata, no sentido que não presta atenção a nada que lhe seja externo, a nenhuma representação (que pode ser de carácter mítico). Está fora do direito e do Estado. É uma violência destruidora da lei, a violência ilegítima, e em nome da vida sobre todo o vivente. ${ }^{36}$ É uma inter- 
rupção do Estado de excepção que foi tornado regra - deixa o Direito sem violência de aplicação e a violência sem fins. Benjamin procura uma aniquilação da textura de continuidade histórica instaurada pelos vencedores pela violência mítica. Neste sentido, procura a ruptura e pretende a suspensão do jogo dialéctico.

Percebemos então que, para Walter Benjamin, o Direito e a lei têm como essência a violência. Mas, a associação entre a lei e a violência deve-se à aplicação de um "Estado de excepção", garante de pacto social, que se foi tornando cada mais regra e não excepção. Benjamin indaga o porquê de, na política ocidental, este Estado de excepção constituir um fundamento invisível de todo o fundamento jurídico e assumir um estatuto quase sagrado. Ao referir a questão da violência pura ("divina"), põe em causa essa continuidade associativa de lei-violência. Assim sendo, a violência pura, não é nada mais do que a própria suspensão dessa continuidade (o estado de excepção que se tornou regra), garantindo assim o espaço para a verdadeira política depurada da violência do Direito, assentando na comunicação.

\section{d) A subversão como destruição do Estado: dialéctica da violência política}

Como vimos, na tradição política ocidental moderna, a questão da violência parece ser um ponto indissociável do Estado, mesmo (e de acordo com Arendt) que um não se reduza ao outro. Contudo, como veremos a seguir, num contexto de guerra anti-colonial, de autodeterminação de povos e de final de Guerra Fria, esta associação começa a tornar-se cada vez mais irrelevante. Não que antes não houvesse violência política para além do Estado, porém a relação directa entre Estado e violência começa por se tornar demasiado redutora como chave de análise.

Lembremos pois a distinção clássica de Pierre Hassner que, na década de 1970, apontava três níveis de violência política: um que cingia ao nível internacional (tendo como pano de fundo a tenção bipolar da Guerra Fria); outro que estava ao nível do Estados (no âmbito nacional e da relação diplomática com outros Estados); e por fim um terceiro nível que se referia à violência infra-Estado (dinâmica sociopolítica interna) ${ }^{37}$ Esta perspectiva parece-nos hoje desactualizada, pois ainda está completamente centrada no Estado. Contudo, ainda lhe reconhecemos uma certa pertinência e utilidade.

Se partirmos da perspectiva de topo, ou seja o Estado, a análise cairá sempre no actor político que ou age pelo poder estatal ou tenta tomá-lo seja porque forma for. Se partirmos por dentro, sociedade ou o interior dos Estados, a análise da 
violência no actor político estará também latente. Muito embora não se possam reduzir analiticamente um ao outro, a violência parece permanecer indissociável do Estado. Essa relação vai esbatendo-se à medida que abandonarmos a abordagem conceptual centrada na Teoria Política Clássica e formos entrando numa componente mais contemporânea de análise da violência política.

Se anteriormente aludimos à violência como origem da lei e como modo quotidiano da sua reprodução, agora referir-nos-emos à violência política como destruição de instituído. Ou seja, referimo-nos à violência na sua perspectiva antitética, como motor de subversão.

Na subversão está implícito o acto ou efeito de subverter, o que, em si, implica a existência de uma ordem prévia que se quer ver corroída. Essa corrosão visa, no imediato, uma mudança brusca, impondo uma ordem divergente da anterior. Portanto, a subversão, como corrosão de um dado sistema ordenado, é um instrumento de acção efémero, que tem como fim último a mudança. Esta forma de acção poderá ser encarada como «um processo social conducente a uma ruptura, total ou parcial, de uma dada ordem conjuntural e caracterizado pela informalidade ou marginalidade de actuações». ${ }^{38}$

Neste sentido, depreendemos que, para além de ser marginal e visar a derrocada do status quo, os projectos que elevam este fenómeno caracterizam-se pela incompatibilidade relativamente aos valores, ordem jurídica, social e política da situação vigente. Na subversão está latente um quase processo dialéctico entre a conservação e a destruição do existente. De uma forma continuada, e por vezes eivada pelo uso da força, a acção subversiva procura a corrosão e destruição de instituições e sistemas sociais, visando a queda da ordem instituída, como se disse há pouco.

É importante ter conta que, associada à problemática da classificação da subversão, podemos encaixar uma dança entre a legitimidade e a legalidade. Tal facto leva-nos sempre a colocar a questão sobre quem é que define o que é subversivo - o movimento que leva a cabo a acção subversiva (que advoga para si a legitimidade) ou a ordem estabelecida que o pode perseguir e punir (que advoga para si a legalidade)?

Posto isto, nunca é demais referir que em sociedades abertas, pautadas pelo jogo democrático e por um Estado de direito, e onde as liberdades civis são pedra de toque, torna-se complicado definir onde acaba a contestação legal e legitima e onde começa a acção subversiva. Deste amplo leque de contestação podem advir 
formas que vão desde o pacifismo à acção armada. Ainda no caso das democracias ocidentais, há que ter em conta que existe uma linha ténue entre a resposta que garante a estabilidade e a resposta que fecha uma sociedade aberta, o que, de uma certa forma, não deixa de ser uma vitória de quem a tenta subverter.

Para completar este esquisso, podemos então dizer que são diversas as teorias e autores que versam as causas da subversão em geral. A actuação subversiva é objecto de estudo de diversas disciplinas. Neste sentido encontramos três formas de abordar este fenómeno transversal. Uma de carácter mais circunstancial, centrada numa forma de conflitualidade política externa ou intra-estatal, que procura causas e fins do movimento perpetrador da acção, bem como o tipo de resposta a ter em conta - estamos, portanto, no campo da análise politológica e polemológica. Há também a componente legal do combate à acção subversiva que reside no campo da jurisprudência, mais propriamente do foro do Direito Penal e Constitucional. E por fim, há uma outra, mais conceptual, que analisa a essência do fenómeno subversivo partindo da filosofia política e assentando na análise da dinâmica social.

Associada ao fenómeno subversivo está a problemática da mudança social. Convém pois referir que todas as acções subversivas visam uma mudança social, mas nem todas as formas de mudança social são subversivas. A este respeito faz sentido mencionar a atenção que alguns autores da Sociologia Teórica Geral contemporânea prestam à problemática da mudança social ${ }^{39} \mathrm{Ou}$ ainda relembrar a importância que esta questão teve, associada à ideia de "ordem" vs. "progresso", nas escolas positivistas e evolucionistas do séc. XIX que pretendiam sobretudo descrever e explicar as tendências das sociedades humanas e da humanidade em geral. ${ }^{40}$ Neste registo, relevamos então a importância do acréscimo do instrumento sociológico que permitiu perceber a mudança social como uma característica perene da vida das sociedades, cuja sensibilidade e significância se revelam directamente proporcionais à complexidade dos sistemas sociais e ao desenvolvimento tecnológico e económico. ${ }^{41}$

Para entender a subversão tendo como base analítica a mudança social, há que localizar o fenómeno social e observá-lo numa determinada área e num quadro sociocultural específico, permitindo a sua classificação científica, identificando a forma de mudança, a periodicidade, as causas, os efeitos e as demais variáveis essenciais à análise sociológica. Importa agora definir o que se entende por mudança social e explicar de que forma este conceito sociológico se pode relacionar com a subversão. 
A mudança social deve ser dissociada do acontecimento, que a pode acompanhar ou espoletar. É um fenómeno colectivo, num período específico de tempo (só tendo um tempo referencial no passado é que poderá apontar a alteração), que visa e obriga a uma mudança estrutural (total ou parcial) de certas componentes da organização social, efectivada se houver uma certa permanência temporal (fugindo ao efémero e ao superficial), e que poderá mudar o curso da história de uma sociedade. ${ }^{42}$

Toda a mudança social tem em si um conflito de interesses, traduzidos, na maior parte das vezes, em situações de tensão e incompatibilidade. Os factores para esse conflito poderão ser de origem natural (cataclismos, epidemias...) ou de origem sociocultural (inovações técnicas, científicas ou filosóficas...), afectando a nível individual ou grupal. A subversão, sendo um processo político-social que desencadeia mudança, insere-se neste último quadro. Importa não confundir a subversão, que visa uma mudança social brusca e convulsiva, com outras manifestações que visam mudança mas de uma forma gradual sem ruptura com a continuidade (como movimentos políticos considerados "progressistas" ou "reformistas").

Na mudança está latente uma dimensão conflitual, que no seu limite, tal como frisámos na secção anterior, pode entrar pela violência, visando a ruptura e anulando a ainda possibilidade negocial existente aquando do conflito. Relembramos que esta separação entre violência e conflito surge-nos aqui apenas como uma ferramenta analítica que nos pode ajudar a perceber a subversão como um fenómeno político e social atípico, que, na sua dimensão conflitual, prevê a instrumentalização de algumas formas de violência que visam a corrosão e posterior ruptura da ordem instituída. São portanto formas de violência não "legitimadas" por não serem controladas pelo poder instituído e que visam a derrocada desse próprio poder.

Assim sendo, podemos então balizar o fenómeno subversivo no seu sentido político e defini-lo com base na finalidade política da acção em causa e pelo universo político directamente visado. Não preenchendo estes dois requisitos (finalidade e universo), formalmente é difícil assumir a subversão como sendo uma acção política.

Mas esta caracterização formal serve apenas fins específicos que se prendem com os aspectos metodológicos. Na verdade, um processo de subversão pode não começar com fins intencionalmente políticos, mas, de uma forma indirecta, alcançá-los. Ou seja, tudo o que é subversivo, por regra tem fins e vínculos políticos. Partindo do 
princípio que o processo é conflitual porque visa a mudança, e violento porque procura a ruptura sem possibilidade negocial, podemos dizer que entrámos agora no registo da violência política de carácter dialéctico.

\section{e) Outras representações da violência política: (re)emergências do pós-Guerra Fria}

Como se pôde verificar, as formas violência política que foram aqui delineadas e equacionadas têm em comum duas perspectivas - a instrumentalização da violência e a ligação, intrínseca ou extrínseca, à autoridade, que aqui surge como sinónimo de Estado. Embora esta última perspectiva, como referimos anteriormente e analisaremos em seguida, pareça não fazer sentido num mundo contemporâneo globalizado, facto é que não poderá ser de todo descartada.

A violência política continua como meio para um fim, contudo, quando sobrevém um fim pouco concreto e/ou de carácter metafísico, a componente instrumental parece esbater-se. É nessa dubiedade que convive a violência armada jihadista da al-Qaeda, por exemplo. Por outro lado, se atendermos à divisão de Hassner e a aplicarmos à contemporaneidade, podemos associar a violência política ao nível infra-estatal, ao nível inter-Estatal, e agora, mais do que nunca, a um nível supra-Estatal, ou até, se quisermos, ao nível para-Estatal. Esta apreciação prende-se, mais uma vez, com a questão dos fins. Não que a violência política tenha abandonado fins concretos, pragmáticos e políticos. Porém, hoje, ter-se-ão que equacionar fins de outras dimensões que subordinam o vector político a princípios de carácter metafísico e/ou de retórica religiosa. Naturalmente que estes fins influenciam a forma de os alcançar.

Balizemo-nos na história. Até ao final da Guerra Fria, a dinâmica internacional estruturava-se em torno duma bipolaridade. Com a implosão do império soviético, assomaram-se novas realidades no panorama internacional que puseram em causa esta estrutura clássica de centralização da violência política no controlo do, ou pelo, Estado - nomeadamente com o aparecimento de actores não-Estatais com uma voz cada vez mais audível na cena internacional.

Comecemos pela ideia de globalização que, não tendo uma relação directa com o final da Guerra Fria, acaba por estar a montante e a jusante deste acontecimento. As consequências que daqui advieram influíram manifestamente na teoria clássica da relação Estado/violência, que apontámos há pouco. É 
a partir da década de 1990 que a noção de globalização começa a assumir a forma que hoje lhe reconhecemos, referindo-se à liberalização dos mercados e à internacionalização dos fluxos financeiros, combinada com o incremento de novas tecnologias de informação e comunicação. ${ }^{43}$ Estando envolvida por estes dois cenários - fim da Guerra Fria e globalização -, onde a perspectiva clássica de Estado associado a um determinado espaço territorial deixa de ser ponto de ordem, a geopolítica mundial começa a pôr em causa a relação entre violência e Estado. Facto é que violência política tende em permanecer, mas cada vez menos associada à acção armada inter-Estado, dando lugar a outras formas de acção armada. Estas novas formas foram enquadradas nas chamadas guerras do terceiro tipo. ${ }^{44}$

Este volte-face geopolítico, caracterizado pelo epílogo de algumas meta-narrativas politicas totalizantes ${ }^{45}$ e pelo reposicionamento de uma determinada forma cultural e política (patente no espraiar da globalização), levou a que outros fins para a violência política, que não no imediato a conservação ou a derrocada do Estado, (re)surgissem. ${ }^{46}$ Assim, no pós-1989, abandonando, mas não por completo as concepções políticas de esquerda/direita e de auto-determinações nacionalistas que tanto caracterizaram a segunda metade do século passado, começam por se manifestar violentamente movimentos anti-globalização, movimentos de cariz étnico, movimentos religiosos, etc. Paralelamente, em resposta à globalização e à implosão do império soviético, assistiu-se a uma desterritorialização da violência política, levando a uma leitura mais inter-comunal do que inter-estatal dos confrontos bélicos latentes.

Não queremos com isto dizer que os nacionalismos e/ou extremismos políticos estão mortos - são exemplos do contrário o confronto israelo-palestiniano ou movimentos como os bascos do Euskadi ta Askatasunausam (ETA) -, mas, analisar a violência somente em termos de relação com o Estado, não chega. Porém, historicamente, esta perspectiva não deixa de ser relevante para perceber algumas dinâmicas de luta, nomeadamente na derrocada e instauração de futuro Estado. Todavia também não é só por aí. A nosso ver ainda há uma certa actualidade nesta dinâmica.

No caso do jihadismo global e da al-Qaeda, o simples facto dos fins perpassarem por uma retórica religiosa, serem globais e de só se prever serem alcançados no final de uma longa linha temporal, oblitera, à partida, a relação Estado e violência. Porém, note-se que ela está lá bem presente. O Califado Global não deixa de 
ser uma forma de Estado, ou de comunidade política. Pode acrescentar-se ainda a essa obliteração o facto da instrumentalização da violência (meio) que, para se perpetuar activamente, necessita de surgir e se justificar como um fim em si. ${ }^{47}$

\section{f) Conclusão}

Assumindo a transversalidade e a impossível contenção da temática, este breve ensaio teve uma função mais descritiva do que propriamente analítica. Nele pretendemos criar um lastro conceptual que sirva de almofada para uma abordagem da problemática da violência associada à subversão.

Incidindo sempre nos fins, levámos então a cabo uma análise teorética sobre a violência política quer ao nível macro quer ao nível micro. No primeiro caso, o nível macro, esteve latente uma motivação racional para a violência social e internacional. No segundo caso, nível micro, essa motivação apareceu como inconsciente e irracional, mesmo não o sendo. No fundo, procurámos demonstrar as diversas nuances da violência política. Daqui, balizado o conceito de violência política, procurámos ainda evidenciar a importância do Estado, ou outra pretensão formal de controlo político, como eixo da análise desta forma de violência.

Posteriormente, foi ainda analisada a violência política já não como génese, nem como a manutenção, mas sim como forma de corrosão de Estado. Entrámos assim no campo da subversão, que pode ser armada, onde um desencadear de violência política de uma forma não institucional.

Foi também tida em conta outra dimensão, que não a puramente instrumental, da violência política. Sendo que essa dimensão se revelará fundamental para interpretar a subversão armada do pós-Guerra Fria, nomeadamente aquela em nome do Jihadismo Global perpetrada pela al-Qaeda. Com efeito, os conflitos armados de hoje tendem a desenrolar-se mais entre actores não-estatais, do que entre Estados, assumindo assim características de guerra irregular e de baixa intensidade.

Sendo um fenómeno abrangente, entendemos a subversão como um conceito integrador de diversas estratégias violentas de corrosão do poder formal. São, portanto, guerras do foro político que, pelo desgaste prolongado do status quo vigente, procuram o estabelecimento de uma nova ordem. 
Felipe Pathé Duarte (101-123)

\section{Referências Bibliográficas}

AA.VV.; Polis: Enciclopédia Verbo da Sociedade e do Estado; vol. 5; Lisboa: Editorial Verbo

Arendt, Hannah; Da Violência; trad. port.; Brasília: Editora Universidade de Brasília, 1985.

Benjamin, Andrew e Osborne, Peter (coord.); A Filosofia de Walter Benjamin; trad. port.; Rio de Janeiro: Ed. Zahar, 1997.

Benjamin, Walter; Para una Crítica de la Violência; trad. cast.; edição online www.philosophia.cl/ Escuela de Filosofia Universidad ARCIS; s/d.

Bredekamp, Horst; "From Benjamin to Carl Schmitt, via Thomas Hobbes"; in Critical Inquiry, Winter, 1999, vol. 25, n. ${ }^{\circ} 2$; pp. 247-266.

Buffacchi, Vittorio; "Two Concepts of Violence"; in Political Studies Review; n³; 2005; pp. 193-204.

Cooper, Robert; The Breaking of Nations: Order and Chaos in the Twenty-First Century; Londres: Altantic Books, 2003.

Duarte, Felipe Pathé; No Crepúsculo da Razão: Considerações Sobre o Terrorismo Pós-Guerra Fria; Lisboa: Prefácio, 2007.

Hammes, Thomas, The Sling and the stone - on war in the 21st Century. Zenith Press, 2004

Hassner, Pierre; La Violence et la Paix: de la Bombe Atomique aux Nettoyage Éthnique; Paris: Éditions du Seuil ; 1995.

Hobbes, Thomas; Hobbes's Leviathan: Reprinted from the Edition of 1651; Londres: Oxford University.

Man and Citizen: De Homine and De Cive; trad. ing.; Londres: Hackett Publishing; 1991.

Holsti, Kalevi J.; The State, War and the State of War; Cambridge, RU: Cambridge University Press, 1996.

Lara, António de Sousa; Ciência Política - Estudo da Ordem e da Subversão; Lisboa: Instituto de Ciências Sociais e Políticas, 2005.

Lyotard, Jean-François; La Condition Postmoderne: Rapport sur le Savoir; Paris: Les Editions de Minuit, 1979. 
Rocher, Guy; Sociologia Geral; vol. 4; trad. port.; Lisboa: Editorial Presença, 1981.

Schelkle, Waltraud et al. (coord.); Paradigms of Social Change: Modernization, Development, Transformation, Evolution; Nova Iorque: St. Martin's Press, 2000.

Schmitt, Carl; The Concept of the Political; trad. ing.; Nova Jérsia: Rutgers University Press, 1976.

Sartori G.; "The essence of the Political in Carl Schmitt"; in Journal of Theoretical Studies; Vol. I, Jan. 1989; pp. 63-75.

Scruton, Roger; O Ocidente e o Resto; trad. port.; Lisboa: Guerra e Paz Editores, 2006.

Simmel, Georg; Conflict and the Web of Group Affiliations; trad. ing.; Glencoe, IL: Free, 1955.

Sorel, George; Reflections on Violence; trad. ing.; Londres: Collier-Macmillan, 1961.

Sztompka, Piotr; The Sociology of Social Change; Oxford: Blackwell Publishers, 1993.

Weber, Max; "A Política como Vocação"; in Gerth, H. H. e Mills, C. Wright (coord.); Max Weber - Ensaios de Sociologia; trad. port.; Rio de Janeiro: Ed. Zahar; 1979.

Weber, Max; Economy and Society; trad. ing.; Los Angeles: University of California Press; 1978-301.

Wieviorka, Michel; The Making of Terrorism; trad. ing.; Chicago: The University of Chicago Press, 1993.

Violence-A New Aproach; trad. ing.; Londres: Sage Publications, 2009.

1 Macedo, Jorge Borges; "Violência"; in AA. VV.; Polis: Enciclopédia Verbo da Sociedade e do Estado; vol. 5; Lisboa: Editorial Verbo, 1983-1987; pág. 1686.

2 Cf. Buffacchi, Vittorio; "Two Concepts of Violence"; in Political Studies Review; n. ${ }^{\circ}$ 3; 2005; pp. 193-204.

3 Etimologicamente a palavra violência advém do latim violentia, a qualidade do violentus, e tem a raiz no vocábulo vis, que significa força, e no sufixo lentus, que remete para uma ideia de continuidade. É violento aquele que continuamente usa a força.

4 Cf. Buffacchi, 2005; pág. 195

5 Cf. Arendt, Hannah; Da Violência; trad. port.; Brasília: Editora Universidade de Brasília, 1985. 
Felipe Pathé Duarte (101-123)

$6 \quad$ Cf. Ibid.; pág. 20.

7 Sobre a dicotomia violência/conflito cf. Simmel, Georg; Conflict and the Web of Group Affiliations; trad. ing.; Glencoe, IL: Free, 1955; Wieviorka, Michel; The Making of Terrorism; trad. ing.; Chicago: The University of Chicago Press, 1993; Violence - A New Aproach; trad. ing.; Londres: Sage Publications, 2009

8 Referimo-nos a Carl Schmitt e talvez a uma das suas formulações mais conhecidas, por referir que uma das diferenciações da ideia de Político (relativamente a outras actividades do Homem) é nela estar latente uma dimensão de conflitualidade assente na dualidade entre "amigo" e "inimigo", que designa um grau extremo de ligação ou separação social e política. Neste registo, o "inimigo" é o outro, uma alteridade diversa e potencialmente aniquiladora, que, num limite, pela negação absoluta, poderá desencadear a guerra, ou seja, a possível negação ontológica. Em termos genéricos, para Schmitt, a relação política entre os homens é sempre conflitual, surgindo o Estado-nação vestefaliano como pólo catalisador dessa diferenciação e a ideologia como rastilho de conflito. Sobre este assunto cf. Schmitt, Carl; The Concept of the Political; trad. ing.; Nova Jérsia: Rutgers University Press, 1976 e sobre Schmitt cf. Sartori G.; "The essence of the Political in Carl Schmitt"; in Journal of Theoretical Studies; Vol. I, Jan. 1989; pp. 63-75.

9 São disto exemplo os movimentos sindicais

10 Cf. Simmel, 1955.

11 «(...)isso só pode ser explicado admitindo-se que, mesmo para os socialistas mais bem informados, os problemas relacionados com a violência tem, até agora, permanecido muito obscuros». Sorel, George; Reflections on Violence; trad. ing.; Londres: Collier-Macmillan, 1961; pág. 60. Tradução livre do autor, que optou em não inserir os textos, originais ou traduções, por considerar que a leitura deste artigo se afiguraria demasiadamente densa.

12 Cf. Arendt, 1985; pág. 20.

13 Cf. Hobbes, Thomas; Hobbes's Leviathan: Reprinted from the Edition of 1651; Londres: Oxford University Press, 1962

14 Hobbes, 1962; Pág. 95

15 Cf. Hobbes, Thomas; Man and Citizen: De Homine and De Cive; trad. ing.; Londres: Hackett Publishing; 1991; pág. 101.

16 Cf. Hobbes, 1991; pág. 11.

17 Cf. Hobbes, 1962; pág. 131

18 Hobbes aborda esta questão comparando o homem a outros animais que vivem em sociedade, como as abelhas, onde não há competição, apenas inclinação natural para a demanda do bem comum. Esta inclinação é artificial nos homens, provém do pacto social que instaura o poder, sendo que o soberano (homem ou assembleia) está fora do contrato (cf. Hobbes, 1962; pág. 131) Aí o seu poder, já existente enquanto direito natural, é aumentado por aquele que os súbditos lhe confiam. O carácter absoluto desse poder ao mesmo tempo que garante da sua estabilidade é o também garante da sua legitimidade. Tem que estar acima dos súbditos (por forma a que não seja partilhado ou mitigado) mas também autorizado por eles através do pacto social. No risco de poder de absoluto de tornar despótico, Hobbes não prevê a concessão de direito de resistência aos súbditos, pois destruiria todo o conceito de autoridade - muito embora admita, em caso de risco de vida dos súbditos, a recuperação do direito natural, alienado aquando do pacto de soberania. (cf. Hobbes, 1962; pág. 259).

19 Weber, Max; "A Política como Vocação"; in Gerth, H. H. e Mills, C. Wright (coord.); Max Weber - Ensaios de Sociologia; trad. port.; Rio de Janeiro: Ed. Zahar; 1979.

20 Para este ensaio seguimos uma tradução inglesa. Cf. Weber, Max; Economy and Society; trad. ing.; Los Angeles: University of California Press; 1978; pp. 212-301. 
21 Cf. Arendt, 1985.

22 Ibid.; pág. 30.

23 A situação apontada é facilmente verificada em regimes totalitários que assentam num estado policial que, num certo momento, assume uma posição autofágica e de Saturno - consumindo-se devorando os seus próprios filhos

24 Por crítica entendemos, em sentido kantiano, separação, distinção, delimitação essencial do objecto de estudo.

25 Para esta dissertação seguimos uma tradução em castelhano. Cf. Benjamin, Walter; Para una Crítica de la Violência; trad. cast.; edição online www.philosophia.cl / Escuela de Filosofia Universidad ARCIS; s/d.

26 Segundo o dicionário de tradução Alemão-Português, o substantivo Gewalt significa força, violência poder ou autoridade (Dicionário de Alemão-Português; Porto: Porto Editora; 1986). Walter Benjamin terá como mote o duplo significado de Gewalt em língua alemã: poder e violência.

27 Na já mencionada obra de Sorel, há uma associação entre mito e violência. Este facto verifica-se quando o actor de violência política não concilia os meios de acção com os fins e entra em contradição com a realidade de onde parte. A violência torna-se então expressão de um mito - uma construção que permite a conciliação do contraditório no imaginário. O mito surge aqui não como concepção utópica (teleológica), mas como um excesso de realidade que num momento suspende noutro torna possível a accão histórica. É, portanto, uma ruptura. Naturalmente que esta associação (mito e violência) põe de parte a visão instrumental da violência. Para Sorel, o exemplo máximo dessa associação seria o mito de uma greve geral. Este registo não instrumental, será fonte para o ensaio crítico de Walter Benjamin. Sobre este assunto cf. Sorel, 1961.

28 Benjamin explora a questão do poder soberano e do estado de excepção patente no pensamento de Carl Schmitt, bem como a recondução da violência pura à ordem jurídica. No facto de o poder soberano decidir sobre o estado de excepção, Schmitt anula toda a legitimidade e possibilidade de uma violência revolucionária e subversiva. Sobre esta assunto cf. Bredekamp, Horst; "From Benjamin to Carl Schmitt, via Thomas Hobbes"; in Critical Inquiry, Winter, 1999, vol. 25, n. ${ }^{\circ}$ 2; pp. 247-266; Schmitt, Carl; The Concept of the Political; trad. ing.; Nova Jérsia: Rutgers University Press; 1976.

29 Cf. Benjamin; pág. 2.

30 Cf. Benjamin; pág. 7.

31 Cf. Ibid.; pág. 13.

32 Cf. Hamacher, Werner; "Aformativo, Greve. A 'Crítica da Violência' de Benjamin"; in Benjamin, Andrew e Osborne, Peter (coord.); A Filosofia de Walter Benjamin; trad. port.; Rio de Janeiro: Ed. Zahar, 1997; pág. 123.

33 Cf. Benjamin; pág. 14

34 Cf. Benjamin; pág. 16.

35 Pura porque não serve de meios para fins situados fora da esfera da mediatiza.

36 Cf. Benjamin; pág. 16.

37 Cf. Hassner, Pierre; La Violence et la Paix: de la Bombe Atomique aux Nettoyage Éthnique; Paris : Éditions du Seuil; 1995

38 Lara, António de Sousa; Ciência Política - Estudo da Ordem e da Subversão; Lisboa: Instituto de Ciências Sociais e Políticas, 2005; pág. 302.

39 Cf. Rocher, Guy; Sociologia Geral; vol.4; trad. port.; Lisboa: Editorial Presença, 1981; Sztompka, Piotr; The Sociology of Social Change; Oxford: Blackwell Publishers, 1993; Schelkle, Waltraud et al. (coord.); Paradigms of Social Change: Modernization, Development, Transformation, Evolution: Nova Iorque: St. Martin's Press, 2000 
Felipe Pathé Duarte (101-123)

40 A este respeito relevamos as obras de August Comte, Karl Marx, Herbert Spencer ou de Émile Durkheim.

41 Cf. Lara, 2005; pp. 302-303.

42 Cf. Rocher, 1981; pp. 89-92.

43 O conceito de globalização é deveras controverso, pelo que, para evitar enredarmo-nos num novelo conceptual, optámos por partir da definição de Roger Scruton - cf. Scruton, Roger; O Ocidente e o Resto; trad. port.; Lisboa: Guerra e Paz Editores, 2006; pp. 113-137.

44 De acordo com Kalevi Holsti as guerras de terceiro tipo surgem por oposicão as guerras "institucionalizadas" características dos séculos XVIII e XIX, e às querras "totais" do século XX (cf. Holsti, Kalevi J.; The State, War and the State of War; Cambridge, RU: Cambridge University Press, 1996 pág. 28). Sentidas sobretudo no rescaldo da Segunda Guerra Mundial, com a assinatura da Carta da Nações Unidas, têm assumido novas forma, e permanecem preponderantes no teatro geopolítico mundial. São guerras irregulares, de carácter subversivo, normalmente desencadeadas por actores não-Estatais, têm um vínculo comunitário e assumem um papel identitário e libertador. São também apelidadas de guerras de "quarta-geração" (cf. Hammes, Thomas, The Sling and the stone - on war in the 21st Century. Zenith Press, 2004).

$45 \mathrm{Na}$ linha de Jean-Francois Lyotard, por meta-narrativa entendemos toda aquela narrativa filosófica que encerra em si uma verdade absoluta sobre o universo. Ideias como a de progresso, razão, história e superação, características do Iluminismo e da Modernidade filosófica, foram traduzida politicamente em visões totalitaristas que marcaram todo o século XX, e que hoje parecem condenadas ao desaparecimento. Esse vácuo, em nossa opinião, veio abrir a porta a reformulações adaptadas a outras realidades dessas mesmas meta-narrativas (cf. Lyotard, Jean-François; La Condition Postmoderne: Rapport sur le Savoir; Paris: Les Editions de Minuit, 1979 e Duarte, Felipe Pathé; No Crepúsculo da Razão: Considerações Sobre o Terrorismo Pós-Guerra Fria; Lisboa: Prefácio, 2007).

46 Lembramos aqui Robert Cooper, quando, na introdução do seu livro "The Breaking of Nations" diz que "O mais preocupante sobre a globalização é que ela nos traz novos, e mais estranhos inimigos cujos motivos que mal podemos compreender» - Cooper, Robert; The Breaking of Nations: Order and Chaos in the Twenty-First Century; Londres: Altantic Books, 2003; pág. xi.

47 Lembramos aqui o conceito de violência divina de Benjamin: uma violência pura e ética por excelência, que inaugura uma época e não é mera repetição histórica. 